\title{
EXTRACTIVES AND ENERGETIC PROPERTIES OF WOOD AND CHARCOAL ${ }^{1}$
}

Antônio José Vinha Zanuncio², Amélia Guimarães Carvalho², Paulo Fernando Trugilho ${ }^{3}$ e Thiago Campos Monteiro ${ }^{4}$

\begin{abstract}
Charcoal production stands out as a raw material for the production of renewable energy. To assess wood quality in energy terms, studies have focused more on the holocellulose and lignin content than on the role of extractives. The objective of this study was to evaluate the relationship between the extractive content in cold water, in dichloromethane and total on energy properties of wood and charcoal, from six trees species. The extractives were removed with different solvents to be recorded and gross calorific value of wood was determined. The wood was carbonized at $1.67^{\circ} \mathrm{C} / \mathrm{min}$ heating rate until maximum of $450^{\circ} \mathrm{C}$ and residence time of $30 \mathrm{~min}$. The extractive content was correlated with the gravimetric yield, apparent relative density, ash, volatile matter, fixed carbon and gross calorific value of charcoal. The removal of total extractives and extractives soluble in dichloromethane reduced the gross calorific value of wood of most species evaluated. The extractives removed in cold water did not correlate with the parameters of carbonization. The extractives content in dichloromethane correlated with volatile matter, fixed carbon and gross calorific value. Total extractive content correlated with gravimetric yield, apparent relative density and gross calorific value of charcoal.
\end{abstract}

Keywords: Gross calorific value; Eucalyptus; Gravimetric yield.

\section{EXTRATIVOS E PROPRIEDADES ENERGÉTICAS DA MADEIRA E DO CARVÃO VEGETAL}

\begin{abstract}
RESUMO - A produção de carvão vegetal se destaca como matéria-prima para a produção de energia renovável. A holocelulose e a lignina são mais abordadas em estudos sobre a qualidade da madeira para fins energéticos, enquanto a influência de extrativos nesse parâmetro é pouco conhecida. O objetivo foi avaliar a relação entre o teor de extrativos em água fria, diclorometano e totais e as propriedades energéticas da madeira e do carvão vegetal de seis espécies. Os extrativos foram removidos com diferentes solventes para serem contabilizados e o poder calorífico superior da madeira, determinado. A madeira foi carbonizada a uma taxa de aquecimento de $1,67^{\circ} \mathrm{C} / \mathrm{min}$, temperatura máxima de $450^{\circ} \mathrm{C}$ e tempo de residência de $30 \mathrm{~min}$. $\mathrm{O}$ teor de extrativos foi correlacionado com o rendimento gravimétrico, densidade relativa aparente, química imediata e poder calorífico do carvão. A remoção dos extrativos totais e solúveis em diclorometano reduziu o poder calorífico da madeira da maioria das espécies avaliadas. Os extrativos em água fria não se relacionaram com os parâmetros da carbonização. O teor de extrativos em diclorometano apresentou correlação com o teor de materiais voláteis, carbono fixo e poder calorífico. O teor de extrativos totais se relacionou com o rendimento gravimétrico, densidade relativa aparente e poder calorífico do carvão vegetal.
\end{abstract}

Palavras-chave: Eucalyptus; Poder calorífico; Rendimento gravimétrico.

\footnotetext{
${ }^{1}$ Recebido em 04.05.2013 aceito para publicação em 11.03.2014.

${ }^{2}$ Programa de Pós graduação em Ciência Florestal, Universidade Federal de Viçosa, UFV, Brasil. E-mail: <ajvzanuncio@yahoo.com.br> e<ameliagcarvalho@gmail.com>.

${ }^{3}$ Departamento de Ciências Florestais da Universidade Federal de Lavras, UFLA, Brasil. E-mail: <trugilho@dcf.ufla.br>.

${ }^{4}$ Programa de Pós Graduação em Ciência e Tecnologia da Madeira, Universidade Federal de Lavras, UFLA, Brasil. E-mail:

<tcmforest@yahoo.com>.
} 


\section{INTRODUCTION}

Brazil is the world's largest producer and consumer of charcoal, which is used mainly in metallurgy and steel industries. Studies on the energy properties of wood materials focus on the holocellulose and lignin content. However, extractives, which influence the ignition of biomass and gross calorific value, warrant further research (MÉSZÉROS et al., 2007; TELMO; LOUSADA, 2011).

Extractives are non-cell wall components of varied chemical composition (FENGEL; WEGENER, 1984). They control resistance to decay, and play a role as reserve material and hormones (FENGEL; WEGENER, 1984). Therefore, they are not uniformly distributed in the tree, showing a higher concentration in the bark.

Heartwood and mature wood contain greater quantities of extractives in the xylem, which endow them with different properties (ADAMAPOULOS et al., 2005; LOURENÇO et al., 2008; DÜNISCH et al., 2010; MORAIS; PEREIRA, 2012). Extractive concentrations change within species (NIELSEN et al., 2009; BRAND et al., 2011); age (GOMINHO et al., 2001); site (NIELSEN et al., 2009; BRAND et al., 2011) and storage time (SILVERIO et al., 2011). Extractives improve the natural resistance of wood, and termite and fungal damage increase its concentrations (SJÖSTRÖM, 1981; MORRIS and STIRLING, 2012).

Charcoal is produced by pyrolysis, i.e., the incomplete combustion of wood in environments with a controlled or total absence of oxygen (ANTAL and GRONLI, 2003). The heating rate, pressure, temperature of process as well as wood factors such as chemical, anatomical composition and moisture affect the quality of the charcoal produced (BRAND et al., 2011; ROUSSET et al., 2011).

There are some studies about energetic properties of extractives (MÉSZÁROS et al., 2007), however only a few studies are focused on the production of charcoal. Thus, the objective of this study was to evaluate the relationship between extractive and gross calorific value of wood and gravimetric yield, apparent relative density, volatile matter, fixed carbon, ash and gross calorific value of charcoal.

\section{MATERIALAND METHODS}

A $30 \mathrm{~cm}$ long log was removed $1.3 \mathrm{~m}$ above the ground level, from each of the 7 years old trees from the species Corymbia citriodora, Eucalyptus paniculata, Eucalyptus urophylla, Eucalyptus urophylla $\mathrm{x}$ Eucalyptus camaldulensis, Eucalyptus torelliana $\mathrm{x}$ Corymbia citriodora and from 11 years old Pinus oocarpa trees.

All samples were milled using a Standard Wiley knife mill with a $2 \mathrm{~mm}$ screen. This material was sieved with a 40-60 mesh sieve and the samples were conditionated at temperature of $23 \pm 1^{\circ} \mathrm{C}$ and a relative humidity of $50 \pm 2 \%$.

The extractives soluble in cold water were determined according to the guidelines of the American Society for Testing and Materials - ASTM D-1110-94 (1994). The extractives soluble in dichloromethane were determined according to ASTM D-1108-94 (1994). The total extractives were determined in three steps, an extraction in alcohol toluene (1:2), an extraction in alcohol and a hot water extraction, according to ASTM D-110594 (1994). After the extractions, the wood samples were conditioned in a climatic chamber at temperature of $23 \pm 1^{\circ} \mathrm{C}$ and a relative humidity of $50 \pm 2 \%$ for volatilization of solvents.

The gross calorific values of the woods before and after extraction were evaluated according to ABNT NBR 8633 (ABNT, 1983) and the results subjected to Tukey test at 5\% significance.

Timber was carbonized at $1.67^{\circ} \mathrm{C} / \mathrm{min}$ heating rate, until $450^{\circ} \mathrm{C}$ and $30 \mathrm{~min}$ residence time in electric furnace at atmospheric pressure and controlled presence of oxygen. The gravimetric yield in dry basis was calculated according to the equation: $\mathrm{G}(\%)=((\mathrm{Mc} / \mathrm{Mm}) / 100)$. Where, $\mathrm{G}(\%)$ = Gravimetric yield in dry basis, $\mathrm{Mc}=$ Mass of charcoal produced, $\mathrm{Mm}=$ Mass of carbonized wood in dry basis. The ash, volatile matter and fixed carbon were evaluated according to ABNT NBR 8112 (ABNT, 1983): the gross calorific value according to ABNT NBR 8633 (ABNT, 1983) and apparent relative density according to ABNT NBR 11941 (ABNT, 2003). All these parameters were performed in triplicate.

The relationship between the extractive content and carbonization data was analyzed using Pearson correlation. 


\section{RESULTS}

\subsection{Extractives content}

The extractive content of the wood ranged from 1.41 to $6.94 \%$ in cold water, 0.8 to $7.17 \%$ in dichloromethane and 3.86 to $10.91 \%$ for total extractives (Table 1 ).

\subsection{Wood gross calorific value}

The gross calorific value of wood ranged from 4,576 to 4,603 cal/g for E. paniculata; 4,436 to 4,663 $\mathrm{cal} / \mathrm{g}$ for E. urophylla; 4,654 to 4,787 cal/g for E. urophylla $\mathrm{x}$ E. camaldulensis; 4,722 to 5,105 cal/g for Pinus oocarpa; 4,502 to 4,650 cal/g for C. citriodora and 4,570 to 4,663 $\mathrm{cal} / \mathrm{g}$ for C. citriodora x E. torelliana (Table 2).

\subsection{Relationship between extraction and properties of charcoal}

The gravimetric yield of charcoal ranged from 29.39 to $33.07 \%$, its apparent relative density from 0.354 to $0.570 \mathrm{~g} / \mathrm{cm}^{3}$, volatile matter content from 20.71 to $27.77 \%$, ash content from 0.260 to $1.797 \%$, fixed carbon between 71.54 and $77.49 \%$ and gross calorific value between 7481 and $7720 \mathrm{cal} / \mathrm{g}$ (Table 3).

The correlation coefficient between carbonization parameters and extractives in cold water, dichloromethane and the total ranged from -0.3467 to $0.3067,-0.9366$ to 0.9232 and 0.4891 and 0.9038 , respectively (Table 4 ).

\section{DISCUSSION}

\subsection{Extractives content}

The extractives soluble in cold water in Eucalyptus species was higher than in Pinus, whereas the opposite was recorded for the extractives soluble in dichloromethane and total extractives. Most extractives in eucaliptus species are soluble in cold water (PEREIRA; MIRANDA, 1992; MIRANDA; PEREIRA, 2002; MORAIS; PEREIRA, 2012) and Pinus oocarpa has higher quantities of extractives soluble in

Table 1 - Extractives content extracted from Eucalyptus and Pinus with cold water, dichloromethane and total. Tabela 1 - Teor de extrativos de Eucalyptus e Pinus em água fria, diclorometano e totais.

\begin{tabular}{|c|c|c|c|}
\hline \multirow[t]{2}{*}{ Species } & \multicolumn{3}{|c|}{ Extraction } \\
\hline & Cold water \% & Dichloromethane \% & Total \% \\
\hline E. paniculata & $2.43 \mathrm{~A} \mathrm{~b}$ & $0.80 \mathrm{~B} \mathrm{a}$ & $3.86 \mathrm{C} \mathrm{a}$ \\
\hline E. urophylla & $6.24 \mathrm{~A} \mathrm{~d}$ & $1.82 \mathrm{~B} \mathrm{~b}$ & $9.12 \mathrm{C} \mathrm{c}$ \\
\hline E. urophylla $x$ E. camaldulensis & $6.94 \mathrm{~A} \mathrm{~d}$ & $1.10 \mathrm{~B} \mathrm{ab}$ & $10.37 \mathrm{C} \mathrm{cd}$ \\
\hline P. oocarpa & $1.41 \mathrm{~A} \mathrm{a}$ & $7.17 \mathrm{~B} \mathrm{~d}$ & $10.91 \mathrm{C} \mathrm{d}$ \\
\hline Corymbia citriodora & $4.23 \mathrm{~A} \mathrm{c}$ & $1.41 \mathrm{~B} \mathrm{ab}$ & $6.25 \mathrm{C} \mathrm{b}$ \\
\hline C. citriodora $\times$ E. toreliana & $3.55 \mathrm{C} \mathrm{c}$ & $2.52 \mathrm{~B} \mathrm{c}$ & $7.23 \mathrm{C} \mathrm{b}$ \\
\hline
\end{tabular}

Means followed by the same capital letter per line and lower case letters per column did not differ between them. Médias seguidas de mesma letra maiúscula por linha ou minúsculas por coluna não diferem entre si.

Table 2 - Gross calorific value of Eucalyptus and Pinus wood after extraction in cold water, dichloromethane and total. Tabela 2 - Poder calorífico superior da madeira de Eucalyptus e Pinus após a extração em água fria, diclorometano e total.

\begin{tabular}{cccc}
\hline Extraction & \multicolumn{3}{c}{ Gross Calorific value (cal/g) } \\
\cline { 2 - 4 } & Eucalyptus Paniculata & Eucalyptus urophylla & E. urophylla x E. camaldulensis \\
\hline Whithout extraction & $4592 \mathrm{a}$ & $4663 \mathrm{a}$ & $4787 \mathrm{a}$ \\
Cold water & $4593 \mathrm{a}$ & $4613 \mathrm{ab}$ & $4769 \mathrm{ab}$ \\
Dichloromethane & $4576 \mathrm{a}$ & $4518 \mathrm{bc}$ & $4702 \mathrm{ab}$ \\
Total & $4603 \mathrm{a}$ & $4436 \mathrm{c}$ & $4654 \mathrm{~b}$ \\
\hline Extraction & Pinus oocarpa & Corymbia citriodora & citriodora x E. toreliana \\
\hline Without extraction & $5105 \mathrm{a}$ & $4650 \mathrm{a}$ & 4663 a \\
Cold water & $4991 \mathrm{ab}$ & $4639 \mathrm{a}$ & 4654 a \\
Dichloromethane & $4842 \mathrm{bc}$ & $4577 \mathrm{~b}$ & 4614 ab \\
Total & $4722 \mathrm{c}$ & $4502 \mathrm{~b}$ & 4570 \\
\hline
\end{tabular}

Means followed by the same letter per column did not differ by Tukey test at $5 \%$.

Médias seguidas de mesma letra por coluna não diferem pelo teste de Tukey a $5 \%$.

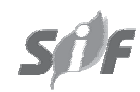

Revista Árvore, Viçosa-MG, v.38, n.2, p.369-374, 2014 
Table 3 - Gravimetric yield, apparent relative density (DEN), volatile matter (VM), ash, fixed carbon (FC) and gross calorific value (GCV) of charcoal from the species studied.

Tabela 3 - Rendimento gravimétrico, densidade relativa aparente (DEN), materiais voláteis (VM), cinzas, carbono fixo (FC) e poder calorífico superior (GCV) do carvão vegetal das espécies estudadas.

\begin{tabular}{cccccc}
\hline Espécie(species) & $\begin{array}{c}\text { Gravimetric } \\
\text { yield }(\%)\end{array}$ & $\begin{array}{c}\text { DEN } \\
\left(\mathrm{g} / \mathrm{cm}^{3}\right)\end{array}$ & $\begin{array}{c}\text { VM } \\
(\%)\end{array}$ & $\begin{array}{c}\text { Ash } \\
(\%)\end{array}$ & $\begin{array}{c}\text { GCV } \\
(\mathrm{FC})\end{array}$ \\
\hline E. paniculata & 29.46 & 0.519 & 22.46 & 0.800 & 76.34 \\
E. urophylla & 33.04 & 0.452 & 23.41 & 0.260 & 7481 \\
E. urophylla x E. camaldulensis & 32.17 & 0.397 & 22.90 & 0.351 & 76.83 \\
P. oocarpa & 33.07 & 0.354 & 27.77 & 0.685 & 76.75 \\
C. citriodora & 31.01 & 0.513 & 20.71 & 1.797 & 7633 \\
E. citriodora x E. toreliana & 29.39 & 0.570 & 23.41 & 0.829 & 77.49 \\
\hline
\end{tabular}

Table 4 - Correlation coefficient between extractives and gravimetric yield, apparent relative density (DEN), volatile matter (VM), ash, fixed carbon (FC) and gross calorific value (GCV) of charcoal from the species studied.

Tabela 4 - Coeficiente de correlação entre extrativos e rendimento gravimétrico, densidade relativa aparente (DEN), matéria volátil (VM), cinzas, carbono fixo (FC) e poder calorífico superior (GCV) do carvão vegetal das espécies estudadas.

\begin{tabular}{cccccc}
\hline Extraction & $\begin{array}{c}\text { Gravimetric } \\
\text { yield }(\%)\end{array}$ & $\begin{array}{c}\text { DEN } \\
\left(\mathrm{g} / \mathrm{cm}^{3}\right)\end{array}$ & $\begin{array}{c}\text { VM } \\
(\%)\end{array}$ & $\begin{array}{c}\text { Ash } \\
(\%)\end{array}$ & $\begin{array}{c}\text { FC } \\
(\%)\end{array}$ \\
\hline Cold water & 0.3067 & -0.0756 & 0.04759 & -0.3467 & 0.5791 \\
$(\mathrm{cal} / \mathrm{g})$
\end{tabular}

dichloromethane, including resins, phytosterols and nonvolatile hydrocarbons (MORAIS et al., 2005).

\subsection{Wood gross calorific value}

The gross calorific values were similar to those reported for Eucalyptus, Pinus and Schizolobium, varying from 4,250 to 4,796 cal/g (BRAND et al., 2011; TELMO; LOUSADA, 2011; FURTADO et al., 2012; SANTOS et al., 2012; VIDAURRE et al., 2012).

Removal of the extractives did not reduce the gross calorific value for E. paniculata due to its low concentration. For all species, removal of the extractives in cold water did not decrease the gross calorific value of the wood.

The extraction in dichloromethane reduces the gross calorific value of E. urophylla; $P$. oocarpa and C. citriodora. This can be explained by the fact that these extractives contain fewer hydroxyl groups and more carbon content (SJOSTROM, 1981), explaining the fact of gross calorific value for extractives soluble in dichloromethane are higher than extractives soluble in cold water. Finally, a reduction in the gross calorific value was observed after total extractive removal in five species.

Revista Árvore, Viçosa-MG, v.38, n.2, p.369-374, 2014
Softwoods have normally higher gross calorific value than hardwoods, which depends in the nature of the lignins, extractive and resin content (SJÖSTRÖM, 1981; TELMO; LOUSADA, 2011).

\subsection{Relationship between extraction and properties of charcoal}

The higher gravimetric yield of charcoal from Pinus oocarpa is due to the nature of lignin (FENGEL; WEGENER, 1984). However, the lower wood density of this group causes lower apparent relative density of chacoal. The higher resin and extractive content in the charcoal after carbonization increases the volatile matter. Softwoods also produce charcoal with higher gross calorific value due to the extractives and the nature of the lignins.

Charcoal samples obtained at $450^{\circ} \mathrm{C}$ do not have extractives soluble in cold water, because it decomposes between 130 and $250^{\circ} \mathrm{C}$ (MÉSZÉROS et al., 2007). Thus, its content was not related to the parameters of carbonization (Table 4).

Extractives soluble in dichloromethane decompose at temperatures between 250 and $550^{\circ} \mathrm{C}$ (MÉSZÁROS, 2007), being present in charcoal produced at $450^{\circ} \mathrm{C}$, increasing volatile matter and reducing fixed carbon. 
These extractives have resistant chemical bonds that release high energy when broken (FENGEL; WEGENER, 1984), giving the charcoal a high gross calorific value.

The relation between the total extractives and gross calorific value is due to the extractives soluble in dichloromethane. No relationship between the extractives and gravimetric yield and apparent relative density of charcoal were found during prior tests, indicating the need of additional tests to determine the classes of extractives that influence these parameters.

\section{CONCLUSION}

Removal of the total extractives and extractives in dichloromethane reduced the gross calorific value of the wood of most plant species evaluated. The extractive content in cold water did not correlate with the parameters of carbonization. However, the extractives in dichloromethane correlated with the volatile matter, fixed carbon and gross calorific value. The total extractive content was related to the gravimetric yield, apparent relative density and gross calorific value of the charcoal.

\section{ACKNOWLEDGEMENTS}

To "Conselho Nacional de Desenvolvimento Científico e Tecnológico (CNPq)”, "Coordenação de Aperfeiçoamento de Pessoal de Nível Superior (CAPES)” and "Fundação de Amparo à Pesquisa do Estado de Minas Gerais (FAPEMIG)”. To Global Edico Services for edition and English review of this manuscript.

\section{REFERENCES}

ADAMAPOULOS, S.; VOULGARIDIS, E.; PASSIALIS, C. Variation of certain chemical properties within the stem wood of black locust (Robinia pseudoacacia L.). Holzforschung. v.63, n.5, p.327-333, 2005.

ALAÑÓN, M. E. et al. Influence of geographical location, site and silvicultural parameters, on volatile composition of Quercus pyrenaica Willd. wood used in wine aging. Forest Ecology and Management, v.262, n.2, p.124-130, 2011.

\section{AMERICAN SOCIETY FOR TESTING AND} MATERIALS - ASTM. ASTM D -1105: Standard test method for preparation of extractive-free wood. Annual Book of ASTM standards: wood. Philadelphia: 1994c.

\section{AMERICAN SOCIETY FOR TESTING AND} MATERIALS - ASTM. ASTM D -1108: Standard test method for dicloromethane soluble in wood. Annual Book of ASTM standards: wood. Philadelphia: 1994b.

\section{AMERICAN SOCIETY FOR TESTING AND \\ MATERIALS - ASTM. ASTM D -1110:}

Standard test method for dicloromethane soluble in wood. Annual Book of ASTM standards: wood. Philadelphia: 1994a.

ANTAL, M. J.; GRONLI, M. The art, science, and technology of charcoal production. Industrial and Engineering Chemistry Research, v.42, n.8, p.1619-1640, 2003.

\section{ASSOCIAÇÃO BRASILEIRA DE NORMAS TÉCNICAS - ABNT. Normas técnicas NBR 8112. Brasília: 1983b.}

ASSOCIAÇÃO BRASILEIRA DE NORMAS TÉCNICAS - ABNT. Normas técnicas NBR 8633. Brasília: 1983a.

\section{ASSOCIAÇÃO BRASILEIRA DE NORMAS TÉCNICAS - ABNT. Normas técnicas NBR 11941. Brasília: 2003c.}

BRAND, M. A. et al. Storage as a tool to improve wood fuel quality. Biomass \& Bioenergy. v.35, n.8, p.2581-2588, 2011.

DÜNISCH, O.; RICHTER, H. G.; KOCH, G. Wood properties of juvenile and mature heartwood in Robinia pseudoacacia. Wood Science and Technology, v.44, n.2, p.301-313, 2010.

FENGEL, D.; WEGENER, G. Wood, chemistry, ultrastructure, reactions. New York: Walter de Gruyter, 1984. 613p.

FREIRE, C. S. R.; SILVESTRE, J. D.; PASCOAL NETO, C. Lipophilic extractives in Eucalyptus globulus kraft pulps. Behaviour during ECF bleaching. Journal of Wood Chemistry and Technology, v.25, n.1, p.67-80, 2005.

FURTADO, T. S. et al. Correlação entre teor de umidade e eficiência energética de resíduos de Pinus taeda em diferentes idades. Revista Árvore, v.36, n.3, p.577-582, 2012.

Revista Árvore, Viçosa-MG, v.38, n.2, p.369-374, 2014 
GOMINHO, J. et al. Within-tree variation of heartwood, extractives and wood density in the eucalypt hybrid (Eucalyptus grandis x $E$. urophylla). Wood Fiber Science, v.33, n.2, p.3-8, 2001.

LOURENÇO, A. et al. The influence of heartwood on the pulping properties of Acacia melanoxylon wood. Journal of Wood Science, v.54, n.6, p.464-469, 2008.

MÉSZÁROS, E.; JAKAB, E.; VÁRHEGYI, G. TG/ MS, Py-GC/MS and THM-GC/MS study of the composition and thermal behavior of extractive components of Robinia pseudoacacia. Journal of Analytical and Applied Pyrolysis, v.79, n.1, p.61-70, 2007.

MORAIS, M. S. M.; PEREIRA, H. Variation of extractives content in heartwood and sapwood of Eucalyptus globulus trees. Wood Science and Technology, v.46, n.4, p.709-719, 2012.

MORAIS, S. A. L.; NASCIMENTO, E. A.; MELO, D. C. Análise da madeira de Pinus oocarpa, parte I - Estudos dos constituintes moleculares e extrativos voláteis. Revista Árvore., v.29, n.3, p.461-470, 2005.

MIRANDA, I.; PEREIRA, H. Variation of pulpwood quality with provenances and site in Eucalyptus globulus. Annals of Forest Science, v.59, n.3, p.283-291, 2002.

NIELSEN, N. P. K. et al. Importance of temperature, moisture content, and species for the conversion process of wood residues into fuel pellets. Wood Fiber Science, v.41, n.4, p.414-425, 2009.
MORRIS, P. I.; STIRLING, R. Western red cedar extractives associated with durability in ground contact. Wood Science and Technology, v.46, n.5, p.991-1002, 2012.

PEREIRA, H.; MIRANDA, I. The chemical composition of wood and bark of fast-grown Eucalyptus globulus L. trees during the first 3 years. Appita, v.37, n.2, p.186-190, 1992.

ROUSSET, P. et al. Pressure effect on the quality of eucalyptus wood charcoal for the steel industry: A statistical analysis approach. Fuel Processing Technology, v.92, n.10, p.1890-1897, 2011.

SANTOS, L. C. et al. Propriedades da madeira e estimativas de massa, carbono e energia de clones de Eucalyptus plantados em diferentes locais. Revista Árvore, v.36, n.5, p.971-980, 2012.

SILVERIO, F. O. et al. Evaluation of chemical composition of Eucalyptus wood extracts after different storage times using principal component analysis. Journal of Wood Chemistry and Technology, v.31, n.1, p.26-41, 2011.

SJÖSTRÖN, E. Wood chemistry. Nova York: Academic Press, 1981. 223p.

TELMO, C.; LOUSADA, J. The explained variation by lignin and extractive contents on higher heating value of wood. Biomass \& Bioenergy, v.35, n.8, p.1663-1667, 2011.

VIDAURRE, G. B. et al. Propriedades energéticas da madeira e do carvão de paricá (Schizolobium amazonicum). Revista Árvore, v.36, n.2, p.365-371, 2012. 